\title{
Comparative Cost Analysis of Four Interventions to Prevent HIV Transmission in Bandung, Indonesia
}

\author{
Eveline J.M. Verstraaten ${ }^{1 *}$, Fenna M.M. Beeren ${ }^{1 *}$, Jip L.C. Janssen ${ }^{1 *}$, \\ Sophie Kemper ${ }^{1 *}$, Adiatma Y.M. Siregar ${ }^{2}$, Noor Tromp ${ }^{1}$, Rob Baltussen $^{1}$
}

${ }^{1}$ Department for Health Evidence, Radboud University Medical Center, Nijmegen, The Netherlands.

${ }^{2}$ Faculty of Economics, Padjadjaran University, Bandung, Indonesia.

*co-main author.

Corresponding Author:

EvelineJ.MVerstraaten.Departmentfor Health Evidence, Radboud UniversityMedical Center.Vrijheidslaan 18-3, 1078PJ_Amsterdam.email:evy_verstraaten@outlook.com.

\begin{abstract}
ABSTRAK
Latar belakang: biaya intervensi HIV/AIDS di Indonesia belum diketahui banyak. Mengetahui biaya-biaya ini merupakan masukan penting bagi pembuat kebijakan dalam membuat keputusan untuk menentukan prioritasprioritas bagi intervesi HIV/AIDS. Tujuan analisis ini adalah untuk menentukan biaya-biaya dari empat intervensi HIV/AIDS di Bandung, Indonesia pada tahun 2015 agar dapat menyediakan informasi bagi komisi AIDS setempat. Metode: data mengenai pemakaian dan biaya berbagai intervensi yang berbeda dikumpulkan di klinik sexual transmitted infections (STI) dan komisi penanggulangan AIDS (KPA) setempat selama bulan Januari 2015 hingga Desember 2015. Biaya-biaya diperkirakan dari perspektif masyarakat menggunakan pendekatan mikro biaya (micro-costing approach). Hasil: total biaya tahunan untuk distribusi kondom, voluntary counselling and testing (VCT) mobile, layanan KIE dan IMS berbasis agama masing-masing setara dengan $\$ 56.926, \$ 2.985, \$ 1.963$ dan $\$ 5.865$ dollar Amerika. Kesimpulan: analisis ini telah menunjukkan perkiraan biaya untuk empat intervensi HIV/AIDS yang berbeda di Bandung, Indonesia. Selain itu, analisis ini telah memperkirakan biaya scaling up intervensi-intervensi tersebut. Secara keseluruhan, hal ini memberikan informasi penting bagi para pembuat kebijakan secara langsung (vis-à-vis) mengenai implementasi intervensi-intervensi tersebut. Meskipun demikian, evaluasi tentang efektivitas intervensi tersebut diperlukan untuk memperkirakan efektivitas biaya.
\end{abstract}

Kata kunci: biaya dan analisis biaya, intervensi medis dini, HIV, Indonesia.

\begin{abstract}
Background: the costs of HIV/AIDS interventions in Indonesia are largely unknown. Knowing these costs is an important input for policy makers in the decision-making of setting priorities among HIVIAIDS interventions. The aim of this analysis is to determine the costs of four HIV/AIDS interventions in Bandung, Indonesia in 2015, to inform the local AIDS commission. Methods: data on utilization and costs of the diff ent interventions were collected in a sexual transmitted infections (STI)-clinic and the KPA, the local HIVIAIDS commission, for the period of January 2015-December 2015. The costs were estimated from a societal perspective, using a micro-costing approach. Results: the total annualized costs for condom distribution, mobile voluntary counselling and testing (VCT), religious based information, communication, and education (IEC) and STI services equalled US\$56,926, US\$2,985, US\$1,963 and US\$5,865, respectively. Conclusion: this analysis has provided cost estimates of four diff ent HIV/AIDS interventions in Bandung, Indonesia. Additionally, it has estimated the costs of scaling up these interventions. Together, this provides important information for policy makers vis-à-vis the implementation of these interventions. However, an evaluation of the eff $\quad$ of these interventions is needed to estimate the cost-eff
\end{abstract}

Keywords: cost and cost analysis, early medical intervention, HIV, Indonesia. 



\section{INTRODUCTION}

Indonesia faces one of the fastest growing HIV epidemics worldwide with a prevalence of 640,000 people living with HIV/AIDS in $2013 .^{1,2}$ For several years, the HIV/AIDS epidemic in Indonesia was concentrated among risk groups like injection drug users (IDUs, prevalence of $40 \%$ in 2013), men who have sex with men (MSM, 13\%) and female sex workers (FSWs, 7\%). ${ }^{3,4}$ However nowadays, the HIV/ AIDS epidemic in Indonesia is shifting towards the general population mostly due to high risk behaviour in homosexual and heterosexual contact such as having multiple partners, low condom use and/or access and a high rate of sexual intercourse - this puts especially IDU's partners and partners of sex workers' clients at risk. ${ }^{5,6}$ The estimated HIV prevalence among the general population has increased from $0.2 \%$ in 2007 to $0.4 \%$ in $2013 .{ }^{7,8}$ Without additional interventions, the total number of people living with HIV in Indonesia was expected to rise to 722,000 at the end of $2016 .{ }^{9}$

Studies suggest that targeting high risk groups is an eff ctive way to prevent further HIV transmission. ${ }^{10,11}$ Moreover, a change in behaviour towards and preconceptions about HIV/AIDS among the general population is essential in tackling the epidemic and can be accomplished by informing and educating the public about the disease and related issues. ${ }^{12,13}$ Indonesia's national response to HIV/AIDS is guided by the National Aids Commission (NAC). The overall aim of this response is to prevent and reduce the risk of HIV transmission, to reduce the social and economic impact of HIV, and to improve the quality of life of people who are HIV positive. ${ }^{5}$ The NAC recommends various interventions, especially for high risk groups, such as condom distribution, harm reduction programmes and voluntary counselling and testing (VCT). ${ }^{14}$ The main targets of this response are to reach $80 \%$ of key populations with effective programmes, ensure that $60 \%$ of them engage in safe behaviour and to make sure that $70 \%$ of programme funding comes from national sources. ${ }^{5}$ In recent years, coverage of these services has expanded to all provinces in Indonesia. ${ }^{5}$ A coverage of at least $80 \%$ among populations most-at-risk is needed in order to induce behaviour change in $60 \%$ of the population, and thereby realise a significant reduction in new HIV infections. ${ }^{15}$

In Bandung, the capital city of West Java province, HIV/AIDS interventions are implemented by different HIV/AIDS organisations and coordinated by the Provincial Aids Commission (Komisi Penanggulangan AIDS, KPA). This commission facilitates among others, condom distribution programmes and religious based HIV/AIDS information, education and communication (IEC). The local non-profi STI community clinic, Klinik Mawar, mostly carries out clinic-based sexual transmitted infections (STI) and voluntary counselling and testing (VCT) services as well as mobile STI and VCT services. Cost analysis concerning HIV interventions is essential to not only support policy makers to use their resources as effi as possible, especially when these resources are scarce, but also to determine the long-term sustainability of an intervention. ${ }^{16}$

In this study costs of four HIV interventions were compared, in the context of the broader PRISMA (Priority setting using multiple criteria) study. PRISMA aims to develop and refine priority setting to support stakeholders during their HIV/AIDS decision-making process. ${ }^{17}$ To our knowledge, no cost data is available on similar HIV/AIDS programmes. Therefore, the aim of this study is to analyse and interpret the costs of several HIV/AIDS interventions in Bandung, Indonesia.

\section{METHODS}

The study was conducted in Bandung, which has a population of 2.4 million people and is the capital of West Java province. The study was conducted together with KPA Bandung and the STI community clinic Klinik Mawar.

\section{Condom Distribution}

KPA distributed condoms 10-15 times a month, to different hot spots in Bandung using a motorbike. Per trip, approximately three hotspots were visited. In total, they distributed to 61 hotspots: 41 street based hotspots, 18 home based hotspots, and two beauty salons. Condoms were distributed in boxes of 144 pieces. The amount 
and frequency of condoms distributed per hotspot was variable and depended on the amount of FSWs that work at the hotspot and the amount of clients that visit the hotspot. In 2015, the amount of condoms distributed per hotspot varied from 288 to 12,960 . Each hotspot has a head of hotspot, who was in charge of the hotspot and keeps the safety of the FSWs. The condoms were provided to the head of the hotspot, who could decide themselves how they further distribute the condoms to their FSWs. Some distributed one box of condoms to one FSW, others distributed 1-10 condoms per FSW. Each hotspot kept KPA informed about the number of condoms, so they knew when to distribute condoms at which hotspot. In addition, the head of hotspots could attend trainings about the basics of HIV and STIs, the best way to distribute condoms and communicate with the FSWs. In 2015, two of these trainings took place (July and November). Each training consisted of 50 participants.

\section{Mobile VCT}

The mobile VCT service, performed by the mobile team of Klinik Mawar, includes HIV testing and counselling of FSW at a hotspot. In 2015 the mobile team went to thirteen diff hotspots (brothels, massage salons, spa, or karaoke). The fi visit included pre-counselling session and taking a blood sample. During the pre-counselling, the counsellor discussed the risks and prevention methods of HIV with the group of FSWs. After this, the blood samples were analysed by a laboratory analyst, in the clinic's laboratory. HIV antibodies were detected with rapid tests. Somebody was diagnosed HIV-positive when three tests resulted reactive. Post-counselling took place two days after the fi visit. The counsellor discussed the results of the HIV test one on one. When the HIV test was reactive the counsellor provides help and set up a referral form for the nearest hospital for further treatment. The clinic did not provide any further treatment or medicines for the HIV-positive FSW.

\section{Religious Based IEC}

The religious based HIV/AIDS IEC intervention was set up in 2014. Approximately once per year KPABandung organized a training on HIV/AIDS which was given to every district in Bandung (30 in total). Per district, three persons received the training from KPA; one Imam of the religion department of the district, one Imam of the MUI (Majelis Ulama Indonesia, this is the Imam organization in Indonesia) and one person of the society. Every year KPA Bandung gave the training to the same districts, and diff people attended. In turn, these three organizations gave training about HIV/AIDS education to a number of Imams in their district. After this district training, the Imams passed their obtained knowledge about HIV/AIDS to the visitors of their religious gatherings. In general the education covers the definition of HIV, the transmission, process of infection and testing of HIV but the specific content of the education depends on the Imam. During one religious gathering a group of 10-20 persons attended, which consist mostly of women.

\section{STI Services}

High risk patients (e.g. FWS, transgenders and MSM) visiting the clinic for a STI test, start with a pre-test counselling session with the nurse or one of the midwives. During this session the patient's sexual background was investigated and brief information on STIs in general was provided. A physical sample was needed from every client which can either be a urethral, cervical, anal or oral swab and/or a blood sample. STIs checked for included gonorrhoea, human papillomavirus (HPV), syphilis, trichomoniasis, herpes, chlamydia, proctitis, bacteria vaginalis, cervicitis and candidiasis. All necessary lab tests were readily available in the clinic. The patient was subsequently informed about the STI test result and, in case of a positive result, received post-test counselling. This included information on the diagnosed STI and additional health risks, treatment plan and setting a new appointment for check-up. Occasionally, informative folders were provided. During this phase, the patient was permitted to ask any remaining questions. All newly attending patients paid a fi amount of 5,000 Indonesian Rupiah (IDR) for the administration fee (0.37 US\$). 


\section{Data Collection, Cost Estimation and Upscaling}

We estimated the costs for a one-year period (January to December 2015) and evaluated them following the WHO manual on costing analysis. ${ }^{16}$ We obtained the costs in April and May 2016 and identified costs from the societal perspective. To estimate the costs as accurate as possible we used a micro-costing approach. ${ }^{18}$ We recorded all costs in Indonesian Rupiah and subsequently converted them to US\$ using the 2015 exchange rate. ${ }^{19}$

We distinguished health care cost (cost generated by usage of resources in the healthcare system) and non-health care cost (cost paid by patients as they seek and undergo care). We further divided the health care costs into capital and recurrent costs. We estimated the costs by conducting interviews and questionnaires with stakeholders and investigated expenditure records and current market prices. In addition, we made various assumptions to complete the data. A more detailed description of the data collection approach and specifi assumptions per HIV intervention can be found elsewhere. ${ }^{24-27}$

To examine the eff of uncertainties in assumed parameters on the documented unit costs, we performed sensitivity analyses. ${ }^{24-27}$ Furthermore, we also estimated costs of scaling up interventions to the highest possible coverage. Besides analysing cost-data, we performed interviews to obtain information about the eff and perceived quality of the interventions. These interviews were held at diff hotspots, mosques, and at the community clinic.

\section{RESULTS}

In 2015, a total number of 21.536 condoms were distributed to 61 different hotspots in Bandung. For mobile VCT, 407 FSW were tested resulting in 25 positive HIV cases. During the religious based IEC, 60 mosques and 1,200 visitors were reached. The in-clinic STI services were performed during a total of 677 high risk patient visits and in $76 \%$ of these visits, the patient appeared to be STI positive.

Table 1 summarizes the total annualized costs per intervention from the societal perspective. The total annualized costs for condom distribution, mobile VCT, religious based IEC and STI services equalled to US $\$ 56,926$, US $\$ 2,985$, US\$1,963 and US\$5,865 respectively. For

Table 1. Annual societal cost per HIV control intervention (in US\$, using 2015 exchange rate).

\begin{tabular}{|c|c|c|c|c|}
\hline \multirow{2}{*}{ Type of Cost } & \multicolumn{4}{|c|}{ HIV intervention } \\
\hline & Condom distribution & Mobile VCI & Relıgıous based ItCC & SII services \\
\hline \multicolumn{5}{|l|}{ HEALTH CARE COST } \\
\hline \multicolumn{5}{|l|}{ Capital (annualized) } \\
\hline Building and space & $1,490.35$ & 12.90 & 706.26 & 117.85 \\
\hline Equipment & 183.70 & 14.06 & 3.33 & 77.26 \\
\hline Training & 166.06 & - & 157.6 & - \\
\hline Vehicles & $8,361.81$ & - & 24.46 & - \\
\hline Sub-total & $10,201.92$ & 26.96 & 891.65 & 195.10 \\
\hline \multicolumn{5}{|l|}{ Recurrent } \\
\hline Building maintenance & 15.97 & 4.91 & 143.11 & 67.57 \\
\hline Personnel & 132.76 & $2,344.26$ & 920.81 & 730.41 \\
\hline Supplies & $44,098.69$ & 318.34 & 1.91 & $1,441.65$ \\
\hline Training & 986.94 & 20.54 & - & 61.29 \\
\hline Transport & $1,190.93$ & 94.10 & 4.48 & - \\
\hline Operational & 298.87 & - & 1.51 & - \\
\hline Sub-total & $46,724.16$ & $2,782.15$ & $1,071.82$ & $2,300.92$ \\
\hline $\begin{array}{l}\text { NON-HEALTH CARE } \\
\text { COST }\end{array}$ & - & 149.34 & - & $3,369.06$ \\
\hline Total annual cost & $56,926.08$ & $2,985.45$ & $1,963.47$ & $5,865.08$ \\
\hline Unit cost & 0.47 & 7.27 & 1.64 & 8.66 \\
\hline
\end{tabular}


condom distribution and STI services, the largest cost share was formed by the supplies. For mobile VCT and religious based IEC, personnel costs were the largest cost component. The unit costs of condom distribution equalled US $\$ 0.47$ per condom. Per FSW tested, the unit costs of mobile VCT provision equalled US\$7.27. The unit costs of the religious based IEC equalled to US\$1.64 per visitor. Lastly, STI services unit costs equalled to US $\$ 6.88$ per high risk patient visit.

The costs of upscaling each intervention to the highest possible coverage are reported in Table 2. The total societal costs of expanding the condom distribution programme to all 69 hotspots in Bandung equalled to US\$62,881. Upscaling of mobile VCT among 2304 FSWs resulted in an overall cost equal to US\$17,462. The annualized total costs of religious based IEC scaled up to two trainings per year (120 Imams trained yearly) equalled to US $\$ 3,604$. To increase the STI services' coverage to $80 \%$ of the total high risk population in Bandung, 43 additional clinics are needed, resulting in a total societal cost equal to US $\$ 258,064$.

As a result of the sensitivity analyses, a unit cost range was determined. For condom distribution the range was US\$0.37-US\$0.57 per condom distributed, for mobile VCT US\$7.18US\$7.68 per FSW tested, for religious-based IEC US\$1.2-US\$2.8 per visitor reached and for STI services US $\$ 8.13$ - US $\$ 9.20$ per high risk patient visit.

\section{DISCUSSION}

This study analysed the costs of four HIV/ AIDS interventions in Bandung, Indonesia. Total costs and unit costs varied between the condom distribution programme (total costs around US $\$ 57,000$, and US $\$ 0.47$ per distributed condom), the STI services (US $\$ 6,000$, and US $\$$ 6.88 per high risk patient visit), mobile VCT (US $\$ 3,000$, and US\$7.27 per tested FSW) and the religious based IEC intervention (US $\$ 2,000$, and US\$1.64 per reached visitor).

This leads to a number of important observations. First of all, the condom distribution intervention in Bandung was relatively cheap compared to condom distribution programmes in other low-income countries as their unit costs per distributed condom ranged from US\$0.72 to US\$3.03. ${ }^{20}$ The largest component of the condom distribution programme was formed by the condom, however quality of the condoms was relatively low, as indicated by the head of hotspots. When the costs of condoms were to be reduced, in order to lower the intervention's expenses, the quality of the condoms had to be taken into account. This was important as condoms should be attractive and functional in order to ensure consistent use..$^{21}$ To what extent the costs per condoms can be reduced while preserving the current eff should therefore be investigated in future cost-effectiveness studies. Secondly, compared to previous studies on Klinik Mawar, unit costs for mobile VCT appeared to be lower than for clinic-based VCT (US\$65). ${ }^{22}$ In addition, the mobile intervention's eff seemed positive. Increasing mobile VCT coverage may therefore be more feasible compared to the inclinic programme. Thirdly, while the religiousbased IEC intervention appear relatively cheap, much remains to be done in order to increase its effects of this intervention. Also, most of the visitors showed a lack of knowledge despite having already received similar HIV/AIDS information, as told by the Imam, via television and/or radio. Before scaling up this intervention, these matters should be assessed and improved. Lastly, although the STI services seem relatively

Table 2. Societal cost (US\$) of HIV control programme upscale scenario (highest possible coverage).

\begin{tabular}{lcccc}
\hline & \multicolumn{4}{c}{ HIV intervention } \\
\cline { 2 - 5 } & Condom distribution & Mobile VCT & Religious based IEC & STI services \\
\hline $\begin{array}{l}\text { Baseline total cost } \\
\text { (US\$) }\end{array}$ & 56,926 & 2,985 & 1,963 & 5,865 \\
$\begin{array}{l}\text { Upscale scenario total } \\
\text { cost (US\$)* }\end{array}$ & 62,881 & 17,462 & 4,250 & 258,064 \\
\hline
\end{tabular}

* In these calculations, start-up, inflation and construction costs are omitted. 
costly, the intervention turned out fi ancially self-sustainable which was strived for by the non-profit clinic. In addition, Klinik Mawar was becoming more independent over the past years as donor dependence is in decline - which is in line with the organization's targets as well.

The difference between the lower and upper bound of the unit costs range constructed after the sensitivity analyses amounts to $154 \%, 107 \%$, $233 \%$ and $113 \%$ in condom distribution, mobile VCT, religious based IEC and the STI services, respectively. Thus, the assumptions made during mobile VCT cost calculations appear to have the lowest influence on the documented unit cost. Outcomes in that study were therefore expected to most precisely represent the actual values, compared to the other three interventions.

We constructed an upscale scenario for every HIV control intervention to predict the cost of the highest possible coverage. Noteworthy, high costs were not the only obstacle making it unable to upscale these interventions to all of Bandung as there appeared to be two additional reasons. For example, the mobile VCT team is unable to reach all hotspots in Bandung as some remain reluctant to receive the medical staff This is because the hotspot's owner is afraid of being forced to stop the business when the government discovers the illegal sexual services provision. Secondly, upscaling the STI services is hindered by additional socio-cultural and organisational barriers due to a shortage of the required resources and labour.

\section{Limitations}

This analysis has various limitations that should be considered. Firstly, various assumptions had to be made in all four analyses. ${ }^{24-27}$ The sensitivity analyses showed that alterations in the assumptions caused deviations in the total societal cost. However, the unit costs of all interventions only varied when the parameters were changed. Secondly, data was collected in only two months and extrapolated to one year. Due to this, some cost data could have been missed out on and in order to complete the data, several assumptions had to be made. Thirdly, certain cost data was based on expert opinion which could have led to over- or underestimations. In addition, the expert had to think in hindsight about the data, which possibly led to inaccuracies. Fourthly, in this analysis only four interventions were taken into account whereas, in reality, there was a wide array of interventions in HIV/AIDS in Bandung. ${ }^{23}$ For this reason, our study findings are only of partial use to inform priority setting in this context. Fifth, we did not systematically assess the eff of the four interventions. Ideally, the cost-data of this study should be combined with an effectiveness analysis to ultimately perform a cost-eff analysis.

\section{CONCLUSION}

This analysis had provided cost estimates of providing condoms to hotpots, mobile VCT among FWS, religious based IEC during mosque gatherings and STI services to high risk patients in Bandung, Indonesia. Subsequently, it had estimated the costs of scaling up these interventions. Together, this provides important information for policy makers vis-à-vis the implementation of these interventions. We call for a systematic evaluation of the effectiveness of these interventions in order to estimate the cost-effectiveness per HIV control programme.

\section{ACKNOWLEDGMENTS}

Our gratitude goes out to the staff of the local community clinic and KPA Bandung for their time and eff in helping us collect the data needed for the analysis. Special thanks go to Riki Relaksana and Estro Sihaloho for their support and translation during the studies. This study was embedded in the PRISMA project, a bigger study executed by the Padjadjaran University, Bandung, Indonesia; and the Radboud University, Nijmegen, The Netherlands.

\section{REFERENCES}

1. Joint United Nations Programme on HIV/AIDS (UNAIDS). Global report: UNAIDS report on the global AIDS epidemic 2012; 2012.

2. AIDS Data Hub. Indonesia Country Profile 2014.

3. Ministry of Health. IBBS among Key Affected Populations (draft results). 2013.

4. Tromp N, Siregar A, Leuwol B, et al. Cost-eff of scaling up voluntary counselling and testing in WestJava, Indonesia. Acta Med Indones. 2013;45(1):17-25.

5. Siregar AY, Komarudin D, Leuwol B, et al. Economic aspect of HIV/AIDS control and injecting drug use in 
Indonesia. Acta Med Indones. 2009;41Suppl1:70-4.

6. Indonesia National AIDS Commission. Republic of Indonesia Country Report on the Follow up to the Declaration of Commitment on HIV/AIDS (UNGASS). 2012.

7. Indonesian NAC. Global aids response progress Reporting: Indonesia Country Progress Report 2014. Reporting period 2012-2013. Indonesian National Aids Commission, 2014.

8. UNGASS. Country report on the follow up to the Declaration of Commitment on HIV/AIDS. National Aids Commission, 2008.

9. Ministry of Health. Estimates and projections of HIV and AIDS in Indonesia, draft. Jakarta, Indonesia: 2014.

10. Aral SO, Blanchard JF. Phase specifi approaches to the epidemiology and prevention of sexually transmitted diseases. Sex Transm Infect. 2002;78Suppl1:11-2.

11. Boily MC, Lowndes C, Alary M. The impact of HIV epidemic phases on the effectiveness of core group interventions: insights from mathematical models. Sex Transm Infect. 2002;78Suppl1:i78-90.

12. Ibrahim S, Sidani S. Community based HIV prevention intervention in developing countries: A systematic review. Advances in Nursing. 2014;2014:11.

13. Kinsman J, Kamali A, Kanyesigye E, et al. Quantitative process evaluation of a community-based HIV/AIDS behavioural intervention in rural Uganda. Health Education Res. 2002;17(2):253-65.

14. Indonesia National AIDS Commission. Country Report on the Follow up to the Declaration of Commitment on HIV/AIDS (UNGASS). Reporting Period 2008 - 2009. National AIDS Commission Republic of Indonesia, 2009.

15. Commission on AIDS in Asia. Redefining AIDS in Asia. Crafting an eff ctive response. New Delhi, India: 2008.

16. Creese A, Parker D. Cost Analysis in primary health care: A training manual for programme managers. World Health Organisation: 1994.

17. Priority setting in HIV/AIDS control at district level in Indonesia [8-7-2016]. Available from: http://niche1. nl/projects/id=33/title=priority_setting_in_hiv_aids_ control_at_district_level_in_indonesia.

18. Drummond MF, Sculpher MJ, Torrance GW. Methods for the Economic Evaluation of Health Care Programmes. New York: Oxford University Press; 2005.

19. The World Bank. World development indicators 20152016, Official exchange rate (LCU per US\$, period average). 2016. Available from: http://data.worldbank. org/indicator/PA.NUS.FCRF.

20. Mvundura M, Nundy N, Kilbourne-Brook M, et al. Estimating the hypothetical dual health impact and cost-effectiveness of the Woman's condom in selected sub-Saharan African countries. Int J Women's Health. 2015;7:271-7.

21. Coffey PS, Kols A, Kilbourne-Brook M, et al. Condom programming for HIV prevention. An operations manual for programming managers. UNFPA, Department of Reproductive Health and Research WHO, PATH.

22. Siregar AY, Komarudin D, Wisaksana R, et al. Costs and outcomes of VCT delivery models in the context of scaling up services in Indonesia. Tropical Med Int Health. 2011;16(2):193-9.

23. Tromp N, Prawiranegara R, Subhan Riparev H, et al. Priority setting in HIV/AIDS control in West Java Indonesia: an evaluation based on the accountability for reasonableness framework. Health policy and planning. 2015;30(3):345-55. Epub 2014/04/18.

24. Kemper, S., Sihaloho, E. D., Siregar, A. Y. M., Tromp, N., \& Baltussen, R. (2016). Cost analysis of religious based HIV/AIDS information, education and communication in Bandung, Indonesia.

25. Verstraaten EJM, Siregar AYM, Tromp N, et al. Cost analysis of mobile voluntary counseling and testing among female sex workers in Bandung, Indonesia [Internet]. Nijmegen, The Netherlands; 2016. Available from: http://niche1.n1/resources/content/publication fi mobile_vct_among_fsw_in_bandung2c_indonesia. pdf.

26. Janssen JLC, Siregar AYM, Tromp N et al. Cost analysis of sexual transmitted infection services for high risk groups in Indonesia [Internet]. Nijmegen, The Netherlands; 2016. Available from: http://niche1. nl/resources/content/publication_file_178_jlcjip_ janssen_cost_analysis_of_sti_services_for_high_risk_ groups_in_indonesia.pdf.

27. Beeren FMM, Siregar AYM, Tromp N, et al. Cost-analysis of condom distribution to hotspots in Bandung, Indonesia [Internet]. Nijmegen, The Netherlands; 2016. Available from: http://niche1. nl/resources/content/publication_file_179_fenna_ beeren_article._condom_distribution_program.pdf. 
